\title{
The politics of the disadvantaged: Observations on work, race and the Polynesian in New Zealand
}

\author{
Paul Spoonley*
}

This article examines the importance of race in the workplace, and the political alternatives open to minority groups such as Polynesians to protect their interests or improve their position with respect to other workers.

\section{Introduction}

Race is an important characteristic in New Zealand society, denials notwithstanding, and it takes on a particular importance in the workplace, especially in the light of the concentration of Polynesian (Maori and Pacific Islander groups) in certain industries and occupations and their complete absence in others (Trlin, 1979). Reasons for this concentration are discussed elsewhere (Spoonley, 1980), and they relate to the beliefs, attitudes and behaviour of those who occupy positions of power in the workplace. Unfortunately, there has been little research undertaken on the people who occupy these positions in New Zealand and their effect on the labour force participation and distribution of Polynesians. An associated issue, and one which again has attracted little academic interest, is the political alternatives open to minority groups to protect their interests or to improve their position in New Zealand society. In a discussion of such options, the workplace provides an important area, partly because it is so central to social life (it is a major factor in determining income, social status and self-esteem), and partly due to the very unequal distribution of Polynesians that currently exists. This inequality suggests disadvantages which provide the impetus for political action. A crucial issue is whether traditional advocacy organisations for the worker, such as trade unions and the Labour Party, are able to represent the particular interests of Polynesians, or whether there is a need for alternative structures and organisations to be developed which will represent those interests.

\section{Polynesians in the Workforce}

The workforce participation of Maoris and Pacific Islanders has only really been an issue since the Second World War when Maoris began migrating from rural areas to the cities, and more recently, Pacific Islanders began migration from various island homelands to New Zealand, in particular to Auckland and Wellington. Prior to this, the rural location of the Maori and his lack of detailed involvement in Pakeha society meant relatively little contact with the trade union movement. Rural employment has always been poorly unionised, although one of the exceptions was the shearing industry which was represented by the Shearers' and Woolshed Employees' Union. In 1914, a quarter of the union membership was Maori, although interestingly, there was an attempt by the employers to establish a Maori Shearers' Association in a classic attempt at divide and rule (Roth, 1973 p. 132). In most cases, however, the relationship between Maori worker and the Pakeha-dominated trade union movement was sporadic and tenuous until migration began (see Roth, 1973).

With migration, the Maori and later the Pacific Islander, encountered a much more organised and extensive trade union movement. But the contact was with quite specific unions. The migration also underlined the marginal nature of Maori participation in the New Zealand workforce. Maoris had few of the skills that were required in an industrialised context, and as a result, they became concentrated in those jobs which required a low skill factor and which were not highly valued by the Pakeha. The 1976 census figures show that 58.7 percent of the Maori workforce is concentrated in the occupational cate-

* Lecturer in Sociology, Massey University. 
gory of Production, Transport, Equipment Operators and Labourers compared with 34.4 percent for non-Polynesians. (An even higher proportion of Pacific Islanders were located in this category: 69.3 percent, or 34.9 percent more than the equivalent figure for non-Polynesians). And these concentrations do not alter when the recency of migration is accounted for (Trlin, 1979). The Maori position in the workforce has largely been determined by shortages of unskilled and semi-skilled labour, the lack or willingness of Pakehas to fill this demand and the racist nature of many aspects of New Zealand society. During boom years, the Maori concentration was not a problem, but with recession, the first to be affected, along with women, were the Maoris and the vulnerability of their position was fully exposed. ${ }^{1}$

The Pacific Islander joined the Maori in the same areas in the labour market and they therefore faced the same problems. As the recession of the 1970s advanced, it became clear that their position was even more tenuous as many were not New Zealand citizens and were seen as legitimate targets for official harassment by the State (Trlin and Spoonley, 1980; De Bres and Campbell, 1976).

Since the 1950s, New Zealand has been able to draw as many unskilled and semiskilled workers from the Pacific Islands as the economy required (De Bres, Campbell and Harris, 1974). Other developed countries of the Pacific rim, notably Japan, Australia and the USA, excluded Pacific Islanders from entering their countries in any number. The only alternative for Pacific Islanders was New Zealand, and in return, New Zealand manufacturers welcomed this flow of labour. An additional and attractive factor for the New Zealand Government was the fact that New Zealand was not required to pay many of the social costs of the migrants, costs that arose from education and other welfare considerations.

A downturn in the early 1970s saw a Labour Government and the succeeding National Government trying to limit the number of Pacific Islanders entering New Zealand and to reduce the numbers who were already here. Strategies included the introduction of a guestworker scheme for groups like Tongans, and even restricted entry and settlement rights for New Zealand citizens like the Cook Island Maori. In 1975, a highly efficient contract labour system was introduced via a work permit scheme for Tongans, Western Samoans and Fijians. The following year, visitors permits for the same three groups were cut from three months to one month, and similar restrictions were placed on Pacific Islanders who were New Zealand citizens (Trlin and Spoonley, 1980). New Zealand had moved into line with European countries such as Switzerland and Germany although the numbers involved in the local schemes cannot compare, even on a relative basis, with those in Europe.

There are a number of advantages to New Zealand from such an approach. The flow of migrants can be easily adjusted in accordance with the requirements of the host society. Families are not brought with the worker and this reduces the costs to New Zealand. It also helps discourage the migrant from settling in New Zealand although the "overstayers" campaign testifies to the fact that this does not always work. The end result is an isolated and dependent workforce whose position is underlined by the "overstayers" campaign and other forms of harassment. The highly capitalised company requires its machinery to be in use for as many hours as possible, and migrants are the ideal workforce for unattractive jobs. This position is made worse by a recession. With job security at risk, the host workers (which may include Pacific Islanders resident in New Zealand) view the migrant as a threat, and inevitably, redundancies, shorter working hours and "rationalisations" affect migrants the most.

1 Unemployment figures for Polynesians are difficult to obtain. Rosenberg (see Trlin, 1979, p. 197) reports that 31.6 percent of all unemployed were Polynesian in 1967, and more recently, the Department of Labour released figures to show that 43.4 percent of Maori females aged 15 years and 30 percent of Maori males of the same age were unemployed compared with 16 percent non-Maori females and 11.3 percent non-Maori males (Evening Post, 30 December 1980, p. 7). 


\section{Strategies for Defending Polynesian Interests}

Given this situation, and with the effects of the recession already visible amongst all Polynesians, it is timely to speculate on some of the strategies that are open to minority racial or ethnic groups to defend their position or to seek further gains from the dominant Pakeha society. There are three broad strategies available (Miles and Phizacklea, 1977). The first is for minority groups to become incorporated into the class structure of the host society so that the issue and problems they face become identified in class terms rather than in racial or ethnic terms. The second strategy involves organisation along ethnic lines with the aim of improving conditions for a particular ethnic group rather than for all Polynesians. And the third possibility is a unity based on colour in response to Pakeha racism.

In the New Zealand context, the first strategy, which sees the development of an interpretation and solution in class terms, seems unlikely, mainly because class polarisation and consciousness are not sufficiently pervasive to encourage class action. A Polynesian who seeks class support is unlikely to be impressed by the response. There are class-based organisations and Polynesians have supported those that represent working-class interests (see Department of Labour, 1979 for evidence on Pacific Islander support for unions). While the relationship between Polynesians and the trade union movement has been cordial, the movement as a whole has done little to actively improve the work situation of Maoris and Pacific Islanders. The New Zealand Federation of Labour Bulletin is much more likely to talk about the problems faced by women than Polynesians; and while the FOL annual conference has discussed racial discrimination for many years now, the discussion has always focused on South Africa and apartheid. Few Maoris and Pacific Islanders hold senior positions in the trade union movement and they are rare among delegates to the annual FOL conference (Roth, 1973). While this may not necessarily reflect dissatisfaction with the trade union movement, it does suggest that Polynesians might look elsewhere for their particular views to be represented, even with regard to those issues that are work-based. Those Polynesians that do hold that a class analysis and action are the most appropriate remain in a minority, and the majority of the Polynesian workforce appears to prefer community-based organisations as opposed to those that are work-based, and these operate as the functional equivalent to the trade union movement but with an ethnic or racial orientation rather than a class one.

The third strategy is based on a coalition of all Polynesians in response to the disadvantages that accompany a brown skin in New Zealand. There seems slightly more reason for expecting that this may become a favoured option than is the case for class-based action. The level of prejudice and discrimination in New Zealand combined with the low economic and social position of the Polynesian could provide the basis or impetus for all Polynesians to identify as one group. Two factors, however, impinge upon the possibility of such a development. The first is that there is a clear distinction drawn by Pakehas, and many Polynesians, between Maori and Pacific Islander for obvious historical reasons. This distinction is exacerbated by the fact that these two groups are competing for similar resources such as housing and jobs. The distinction would need to lessen before a coalition could become a viable option. Secondly, the identity of most individual Polynesian groups is still very strong. Those who have come from the Pacific Islands retain traditional cultural affiliations which is only to be expected given the recency of their migration and the still considerable links with their respective homelands. Maoris, in the face of serious threats to the-continuation of aspects of their culture, are re-evaluating their past and seeking ways to perpetuate many traditional cultural practices albeit in an altered form and in an urban context. This recent assertiveness and the attempt to improve the collective self-image of the Maori will help to reinforce his particular identity, or identities if tribal groupings play an important role. The resurgence has obvious implications for workplace relations and the organisation of work activities. 
There are exceptions to groups based on traditional allegiances. There are pan-Polynesian movements such as Pacifica and the Maori Womens Welfare League but they tend to be predominantly welfare-oriented and to have few broad political ambitions. In contrast are groups like Nga Tamatoa and more significantly Mana Motuhake.

Mana Motuhake represents a split between the aims and objectives of a section of the Maori community and a party that has traditionally claimed to represent Maori interests. Mana Motuhake is an ethnic organisation which seeks to enter the political arena directly and by-pass the longstanding reliance on the Labour Party. It does claim to represent both Maori and Pacific Island interests, although at this early stage, its support among Pacific Island groups seems confined to specific geographic areas (e.g. Porirua). Questions must also be raised about the party's ability to overcome tribal politics and to unify a significant number of Maoris under its banner.

On the other hand, the future for such a movement must be good. In the main cities, and particularly in Auckland, there are now many young Polynesians whose identification with their tribal or island group is minimal and they lack the opportunity to immerse themselves in a cultural setting that would provide them with that identification. Some Polynesian groups have worked hard to maintain links with their young but for an equal and growing number, these links are noticeably lacking. Instead, there is a search for new images and an identity. Some are committed to "gangs" while others have sought a more political stance with ideologies ranging from rastafarianism to American black power strategies and arguments. The rejection of the dominant Pakeha society and the lack of identity with their own cultural past puts the young in a defensive position with a potential for confrontation. But there is also the potential for a more positive political direction and a group like Mana Motuhake which is outside the traditional power structure may be able to harness this potential. The difficulty for Mana Motuhake is to attract and justify this support while operating within the constraints of the political system. Credibility is a central issue.

The younger generations of the Polynesians will be critical in determining whether a unity based on race is possible. The fact that they are likely to be more politicised and aware of the obstacles facing Polynesians in New Zealand means that the future for a group like Mana Motuhake is promising even if their political fortunes at the moment are discouraging.

This leaves the second strategy, a continuing dependence and affiliation with the traditional institutions of a particular ethnic group. An ethnic group will have a series of structures ranging from the kin-based work groups through to more elaborate and extensive church or collectively based organisations, like the Tongan Development Corporation, which operate to ensure the welfare of group members. Faced by restricted access to jobs, housing, welfare services or other resources, these organisations will help group members resolve problems, normally by circumventing them rather than by confrontation. The more competent the group is in solving these problems, then the more likely it is to attract and retain the younger members of the community and to convince them that it is in their interest to stay with the ethnic group. Support creates an obligation for those receiving help and reciprocity patterns help ensure that ethnic traditions are maintained.

One example is provided by the Tongan Development Corporation which is based on the Tongan community in Auckland. It is used to call on community members to provide capital for projects designed to help Tongans. This enterprise ensures participation if for no other reason than the fact that individuals and families are financially involved. This serves to remind members of their commitments to other Tongans and reinforces cultural practices by exposing them to traditional rituals and obligations. The Tongan Development Corporation also helps negotiate with the host community on various matters to ensure that Tongan aspirations are met. But characteristically, the aims of the Corporation have not been explicitly expressed in political terms, nor has the community collectively done much in terms of the formal political process in New Zealand. One exception was the reaction to the "overstayers" campaign where a more political stance was adopted to convey its opposition to the exercise. 


\section{Conclusion}

Ultimately, the strategy adopted (or retained) by Pacific Islanders, and probably all Polynesians, will be influenced by the ability of traditionally based organisations to respond in a political sense to the problems faced by their community members. If those organisations which are based on specific ethnic communities can adopt a greater political profile to encompass the needs of the urban-born generations, then it will ensure their central role in representing group concerns. Their failure, however, would leave the way open to the strategy that centres on race. The younger Polynesians may abandon their ethnic group and forge an alliance with other Polynesians to establish new organisations that will meet their needs. ${ }^{2}$ If Mana Motuhake foreshadows the future, then the strategy based on racial unity would seem the next obvious choice. If this is the case, then minority group organisations will become much more aggressive in their actions. The labour force participation and distribution of the Polynesian would be a central concern of such organisations, and both trade unions and employers would be subjected to very new pressures and debates.

\section{References}

De Bres, J., and R. Campbell (1976) The overstayers : illegal migration from the Pacific to New Zealand Auckland, Auckland Resource Centre for World Development.

De Bres, J., R. Campbell and P. Harris (1974) Migrant labour in the Pacific Wellington, CORSO.

Department of Labour (1979) The work experience of Pacific Island migrants in the greater Wellington area Wellington, Department of Labour.

Miles, R, and A. Phizacklea (1977)Class, race, ethnicity and political action Political studies 25(4): 491-507.

Roth, H. (1973) Trade unions in New Zealand : past and present Wellington, Reed.

Spoonley, P. (1980) The role of gatekeepers in the employment of migrant groups Proceedings of the annual conference, New Zealand Demographic Society, Wellington, New Zealand Demographic Society.

Trlin, A.D. (1979) Race, ethnicity and society, pp. 185-212 in Neville, R.J.W., and D.J. O'Neill (Eds) The population of New Zealand : interdisciplinary perspectives Auckland, Longman Paul.

Trlin, A.D., and P. Spoonley (1980) Goodbye New Zealand! net external migration losses in the 1960s and 1970s. In C.A. Price (Ed) Australian immigration : a bibliography and digest Canberra, Australian National University.

2 This discussion does not allow for the obvious and powerful influence of the State in these matters. The State and its agencies such as the Department of Maori Affairs has a vested interest and could therefore be expected to intervene. 